Article

\title{
Anti-Yeast Synergistic Effects and Mode of Action of Australian Native Plant Essential Oils
}

\author{
Fahad Alderees ${ }^{1}$, Ram Mereddy ${ }^{2}$, Stephen Were ${ }^{2} \mathbb{D}$, Michael E. Netzel ${ }^{1}$ (D) and Yasmina Sultanbawa ${ }^{1, *(D)}$ \\ 1 ARC Industrial Transformation Training Centre for Uniquely Australian Foods, Queensland Alliance for \\ Agriculture and Food Innovation, The University of Queensland, Indooroopilly, \\ Brisbane, QLD 4068, Australia; alderees@gmail.com (F.A.); m.netzel@uq.edu.au (M.E.N.) \\ 2 Department of Agriculture and Fisheries, Health and Food Sciences Precinct, Coopers Plains, Brisbane, \\ QLD 4108, Australia; ram.mereddy@daf.qld.gov.au (R.M.); stephen.were@daf.qld.gov.au (S.W.) \\ * Correspondence: y.sultanbawa@uq.edu.au
}

Citation: Alderees, F.; Mereddy, R.; Were, S.; Netzel, M.E.; Sultanbawa, Y. Anti-Yeast Synergistic Effects and Mode of Action of Australian Native Plant Essential Oils. Appl. Sci. 2021, 11, 10670. https://doi.org/10.3390/ app112210670

Academic Editors: Ionel Calin Jianu and Georgeta Pop

Received: 12 October 2021

Accepted: 6 November 2021

Published: 12 November 2021

Publisher's Note: MDPI stays neutral with regard to jurisdictional claims in published maps and institutional affiliations.

Copyright: (c) 2021 by the authors. Licensee MDPI, Basel, Switzerland. This article is an open access article distributed under the terms and conditions of the Creative Commons Attribution (CC BY) license (https:// creativecommons.org/licenses/by/ $4.0 /)$.

\begin{abstract}
Yeasts are the most common group of microorganisms responsible for spoilage of soft drinks and fruit juices due to their ability to withstand juice acidity and pasteurization temperatures and resist the action of weak-acid preservatives. Food industries are interested in the application of natural antimicrobial compounds as an alternative solution to the spoilage problem. This study attempts to investigate the effectiveness of three Australian native plant essential oils (EOs) Tasmanian pepper leaf (TPL), lemon myrtle (LM) and anise myrtle (AM) against weak-acid resistant yeasts, to identify their major bioactive compounds and to elucidate their anti-yeast mode of action. The minimum inhibitory concentration (MIC), minimum fungicidal concentration (MFC) and minimum bactericidal concentration (MBC) were assessed for EOs against weak-acid resistant yeasts (Candida albicans, Candida krusei, Dekkera anomala, Dekkera bruxellensis, Rhodotorula mucilaginosa, Saccharomyces cerevisiae, Schizosaccharomyces pombe, Zygosaccharomyces bailii and Zygosaccharomyces rouxii) and bacteria (Staphylococcus aureus and Escherichia coli). The EOs showed anti-yeast and antibacterial activity at concentrations ranging from $0.03-0.07 \mathrm{mg} / \mathrm{mL}$ and $0.22-0.42 \mathrm{mg} / \mathrm{mL}$ for TPL and $0.07-0.31 \mathrm{mg} / \mathrm{mL}$ and $0.83-1.67 \mathrm{mg} / \mathrm{mL}$ for $\mathrm{LM}$, respectively. The EOs main bioactive compounds were identified as polygodial in TPL, citral (neral and geranial) in LM and anethole in AM. No changes in the MICs of the EOs were observed in the sorbitol osmotic protection assay but were found to be increased in the ergosterol binding assay after the addition of exogenous ergosterol. Damaging of the yeast cell membrane, channel formation, cell organelles and ion leakage could be identified as the mode of action of TPL and LM EOs. The studied Australian native plant EOs showed potential as natural antimicrobials that could be used in the beverage and food industry against the spoilage causing yeasts.
\end{abstract}

Keywords: Australian native plants; essential oils; weak-acid resistant yeast; natural antimicrobials; anti-yeast activity

\section{Introduction}

Plant essential oils (EOs) have been utilized for many centuries in traditional medicine, as spices, coloring, perfume and aromatherapy [1,2]. Due to their beneficial properties, they have been incorporated in recent years into pharmaceuticals, food preservation, agriculture, disinfection and sanitation products, and cosmetics [3]. There are about 3000 known EOs; however, only $10 \%$ have been commercially utilized in different industries [4,5]. Plant EOs are unique and worth deeper investigation due to their multiple bioactive properties such as being antibacterial, antiviral, antifungal, anti-toxigenic, anti-carcinogenic, antioxidant, anti-parasitic, insecticidal, sedative, anti-inflammatory, antiseptic, spasmolytic and anesthetic $[1,3,4]$. There is a huge opportunity to study and exploit the biological properties of these EOs for novel applications in the food (e.g., as natural preservatives) and pharmaceutical industries. 
In recent years, EOs have been studied for their antimicrobial properties against bacteria, fungi and viruses. However, little is known about their efficacy when compared to synthetic food preservatives, their activity against weak-acid resistant yeasts and mode of action [6-10].

Yeasts are well-known for their positive contributions in the production and development of various foods and beverages. However, some species of yeasts cause negative effects by spoilage [11]. These yeasts can grow in an environment that has a low water activity, low $\mathrm{pH}$, high concentration of sugar/salt, cold temperatures and are able to resist and survive within the legally permitted levels of synthetic preservatives, which creates a real challenge to the food and beverage industries $[6,12,13]$. The scientific literature shows numerous studies referring to the emergence of spoilage yeast resistant to weak-acid preservatives such as acetic acid, benzoic acid, sulfur dioxide and sorbic acid [6,12,13]. Almost every food industry that manufactures acid beverages was exposed to one or more occasions of great economic losses due to yeasts that are resistant to weak-acid preservatives [14]. A great example of the seriousness of this challenge is when yeasts spoiled about 300,000 bottles of orange-based carbonated beverages from one of the manufacturers in Europe [6]. The observed increased resistance is a "wake up call" to look for alternative solutions, and the food industry is interested in exploring the utilization of natural antimicrobial compounds as an alternative pathway to control this spoilage problem [15]. In addition, the pharmaceutical industry is also focusing on incorporating natural products in medications, where about $28 \%$ of all the newly approved drugs were derived from either natural or derivatives of natural compounds [16,17].

The rich Australian indigenous flora contains a variety of plants that are abundant in EOs and phytochemicals with promising biological activities. Three commercially produced plants, Tasmanian pepper leaf (TPL) (Tasmannia lanceolata), lemon myrtle (LM) (Backhousia citriodora) and anise myrtle (AM) (Syzygium anisatum) are known to possess antimicrobial activities. TPL belongs to the Winteraceae family and is located in forested regions in Tasmania, Victoria and north to the Blue Mountains [18]. Polygodial, sesquiterpene dialdehyde, is reported to be the major bioactive compound (37\% to 64\%) in TPL EO contributing to its antibacterial and antifungal activities [18-22]. TPL is utilized commercially in food products as a flavoring, seasoning, coloring and preservative agent [19,23,24]. LM is a member of the Myrtaceae family and grows in the subtropical rainforests of central and southeast regions of Queensland, Australia spreading along the coastal regions from Brisbane to Cairns [25]. LM EO was first steam distilled in 1890 and is used as a flavoring agent in food and beverage systems, cosmetic products, fragrances and aromatherapy [26-29]. The antimicrobial properties of LM are due to its predominant compound ( $82 \%$ to $91 \%$ ) citral, a monoterpene aldehyde [30]. Anise myrtle is a rare Australian native plant found in the moist rainforest areas located in the Bellingen Valley of northeast New South Wales and some nearby parts of Queensland [31]. Its leaves are used as an herb either fresh or as ground powder to provide aniseed flavors in Australian cuisines, and its EO is utilized in cosmetic products, alcoholic beverages and in the pharmaceutical industry [32]. EO of AM consists of anethole (94.97\%) and its isomer methyl chavicol (4.43\%), known as estragole, which contribute to the antimicrobial property [33].

There is a knowledge gap regarding the antimicrobial activity of Australian native essential oils against weak-acid resistant yeasts that are commonly reported to cause spoilage in fruit juices. Therefore, the aims of this study are to evaluate the antimicrobial activities of TPL, LM and AM EOs against nine weak-acid resistant yeasts, Candida albicans, Candida krusei, Dekkera anomala, Dekkera bruxellensis, Rhodotorula mucilaginosa, Saccharomyces cerevisiae, Schizosaccharomyces pombe, Zygosaccharomyces bailii and Zygosaccharomyces rouxii and two food related bacteria Staphylococcus aureus and Escherichia coli, to determine the EOs minimum inhibitory concentration (MIC), minimum fungicidal concentration (MFC), and minimum bactericidal concentration (MBC), and to investigate possible synergistic effects between the three EOs and to elucidate the potential anti-yeast mode of action of these EOs. 


\section{Materials and Methods}

\subsection{Essential Oils and Other Chemicals}

EOs of LM and AM were supplied by Australian Rainforest Products Pty Ltd. (Lismore, NSW, Australia) and EO of TPL was supplied by Essential Oils of Tasmania Pty Ltd. (Margate, TAS, Australia). Oils were kept in their original bottles protected from light and stored at $4{ }^{\circ} \mathrm{C}$ until further use. In all experiments, EOs were applied as emulsions in sterile water with Tween-80 at a ratio of 10:1 (v/v). Nutrient broth (CM0001, Oxoid, Basingstoke, UK), Sabouraud dextrose broth (CM0147, Oxoid, Basingstoke, UK), Tween80 (9005656, Sigma-Aldrich, St. Louis, MO, USA), ergosterol (57874, Sigma-Aldrich, St. Louis, MO, USA), sorbitol (50704, Sigma-Aldrich, St. Louis, MO, USA), Cesium chloride (15507023, Thermo Fisher Scientific, Scoresby, VIC, Australia), Sodium Chloride (Thermo Fisher Scientific, Scoresby, VIC, Australia), DAPI (4',6-diamidino-2-phenylindole) (62247, Thermo Fisher Scientific, Scoresby, VIC, Australia), paraformaldehyde (R37814, Thermo Fisher Scientific, Scoresby, VIC, Australia), poly-L-lysine (25988630, Sigma-Aldrich, St. Louis, MO, USA), glutaraldehyde (ProSciTech, Townsville, QLD, Australia), osmium tetroxide (ProSciTech, Townsville, QLD, Australia), phosphate buffered saline (Sigma P4417, Sigma-Aldrich, Castle Hill, NSW, Australia).

\subsection{Microorganisms}

Antimicrobial testing was performed against two bacteria, Gram-positive Staphylococcus aureus (ATCC 9144) and Gram-negative Escherichia coli (ATCC 11775), and nine yeasts, Candida albicans (ATCC 10231), Candida krusei (ATCC 6258), Dekkera anomala (ATCC 58985), Dekkera bruxellensis (ATCC 56866), Rhodotorula mucilaginosa (ATCC 20129), Saccharomyces cerevisiae (ATCC 38555), Schizosaccharomyces pombe (ATCC 26189), Zygosaccharomyces bailii (ATCC 38923) and Zygosaccharomyces rouxii (ATCC 10682). Microorganisms were purchased from In Vitro Technologies (Melbourne, VIC, Australia).

\subsection{Determination of Antimicrobial Activity}

The minimum inhibitory concentration (MIC), defined as the lowest oil concentration to inhibit visible microbial growth, was performed by a broth serial microdilution method using 96-well plates according to Ahmad and Viljoen [34] with a few modifications. Cultures were grown for $24 \mathrm{~h}$ at $35^{\circ} \mathrm{C}$ in a nutrient broth (CM0001, Oxoid, Basingstoke, UK) for bacteria and at $25^{\circ} \mathrm{C}$ in a Sabouraud dextrose broth (CM0147, Oxoid) for yeasts, except for C. albicans and S. pombe which were grown at $30^{\circ} \mathrm{C}$. Cultures were measured at OD540 $=0.5$ McFarland, diluted (using their designated double strength broth) into $1 \times 10^{5}$ colony forming units (cfu) per $\mathrm{ml}$ and dispensed $(100 \mu \mathrm{L})$ onto the 96-well plates. A stock solution of EO was diluted serially two-fold in $25 \mathrm{~mL}$ centrifuge tubes to give solutions from 1 to $0.002 \%(v / v)$ and $100 \mu \mathrm{L}$ of each concentration was dispensed in triplicate from highest to lowest on the plate. Growth control (culture + broth + Tween-80), sterility control (broth + tween- $80+\mathrm{EO}$ ) and standard drugs as positive control (amphotericin B for yeasts and chloramphenicol for bacteria) were included in every microplate assay test. After incubation for $48 \mathrm{~h}$ for yeasts and $24 \mathrm{~h}$ for bacteria, the absence of a white growth on the bottom of the well was used as an indication of the MIC. The minimum bactericidal concentration (MBC) and minimum fungicidal concentration (MFC) were determined by inoculating $20 \mu \mathrm{L}$ from wells with no observed growth onto a new 96-well plate containing $100 \mu \mathrm{L}$ broth (normal strength) and incubated at the same conditions as described above. Wells with no visible growth and the lowest $\mathrm{EO}$ concentration were determined as the MBC or MFC. The whole procedure was performed in triplicate and the MICs, MBCs and MFCs were expressed in $\mathrm{mg} / \mathrm{mL}$.

\subsection{Ergosterol Binding Assay}

The interaction between EOs and ergosterol was evaluated by observing the MIC changes in the absence and presence of ergosterol at concentrations of 25,50 and $100 \mu \mathrm{g} / \mathrm{mL}$ using a broth serial dilution method on 96-well plates [35]. Ergosterol was dissolved in 
ethanol and Tween-80 $(1: 1, v / v)$ at $40{ }^{\circ} \mathrm{C}$ and $50 \mu \mathrm{L}$ of that solution was dispensed onto the plate. Each well contained $100 \mu \mathrm{L}$ double strength broth and $100 \mu \mathrm{L}$ of EO as previously prepared, with a yeast culture concentration of $1-2 \times 10^{5}$. Growth control (culture + broth + ethanol + tween-80) and sterility controls were included on the same 96-well plates.

\subsection{Sorbitol Osmotic Protection Assay}

The sorbitol assay was performed according to Frost et al. [36] with some modifications using a serial broth microdilution method. The MICs of the EOs were tested without and with the addition of $0.8 \mathrm{M}$ sorbitol in 96-well plates. Sorbitol was dissolved in a double strength broth and $100 \mu \mathrm{L}$ was dispensed onto each well containing $100 \mu \mathrm{L}$ EO at different concentrations as previously prepared. Growth control (culture + broth $+0.8 \mathrm{M}$ sorbitol) and sterility controls were included on the same 96-well plates.

\subsection{Leakage of Potassium and Magnesium Ions}

The concentrations of potassium and magnesium ions were measured before and after exposure of $S$. cerevisiae to LM, TPL and AM EOs using an atomic absorption spectrophotometer (contrAA, Analytik Jena AG, Jena, Germany) following the method of Prashar and co-workers [37] with a few modifications. S. cerevisiae cell suspensions were obtained at turbidity of OD540 $=2.0$ in $5 \mathrm{~mL}$ of $0.1 \mathrm{M} \mathrm{NaCl}$ solution and samples were treated with $0.5 \%(v / v)$ EO for $0,2,4$ and $6 \mathrm{~h}$ at $25{ }^{\circ} \mathrm{C}$ while shaking on an orbital shaker at a speed of $150 \mathrm{rpm}$. Positive control samples (yeast $+\mathrm{NaCl}$ ) and negative control samples (oil $+\mathrm{NaCl}$ ) were exposed to the same conditions as the treated samples and measured at $0,2,4$ and $6 \mathrm{~h}$. A solution of $0.1 \%(w / v)$ cesium chloride was used as an ion suppressant and depending on the concentration of ions, samples were diluted 1:10 or 1:40 with the ion suppressant. Acetylene was used as a fuel and wavelength measurement for potassium and magnesium was set at $766.49 \mathrm{~nm}$ and $285.21 \mathrm{~nm}$, respectively.

\subsection{Synergy Checkerboard (Interactions between EOs)}

The MIC was obtained by testing the EOs individually or in combination to determine if their interaction is of synergistic, additive, indifferent or antagonistic nature, using the checkerboard assay on a 96-well plate according to Zengin and Baysal [38]. The first oil (component A) was dispensed vertically, and the second oil (component B) was dispensed horizontally on the plate from highest to lowest concentration. The Fractional Inhibitory Concentration Index (FICI) is the sum of Fractional Inhibitory Concentration (FIC) of component A (FICA) and FIC of component B (FICB) and was determined based on the following formula: FICA = MIC of component A in combination/MIC of component $\mathrm{A}$ alone, FICB = MIC of component $\mathrm{B}$ in combination/MIC of component $\mathrm{B}$ alone, $\mathrm{FICI}=(\mathrm{FICA}+\mathrm{FICB})$. FICI was considered synergistic, additive, indifferent or antagonistic when values were $\leq 0.5,0.5$ to $\leq 1,1$ to 4 or $>4$, respectively.

\subsection{Fluorescence and Scanning Electron Microscopy}

The morphological changes of $S$. cerevisiae cells treated with EOs were monitored by fluorescence and scanning electron microscopy. An overnight culture suspension was adjusted to $1 \times 10^{5} \mathrm{cfu} / \mathrm{mL}$, pelleted by centrifugation at $2500 \times \mathrm{g} \mathrm{rpm}$ for $5 \mathrm{~min}$ and treated with $0.5 \%$ oil for $2 \mathrm{~h}$ at $25^{\circ} \mathrm{C}$. The control group was treated the same way, except that 0.1 M phosphate buffered saline (Sigma P4417, Sigma-Aldrich, Castle Hill, NSW, Australia) replaced the EOs. After the treatment, $S$. cerevisiae cells were harvested by centrifugation at $2500 \times g \mathrm{rpm}$ for $5 \mathrm{~min}$ and washed twice with $0.1 \mathrm{M}$ phosphate buffered saline.

\subsection{Fluorescence Microscopy and Yeast Cell Staining}

Two fluorescent dyes, DAPI (4',6-diamidino-2-phenylindole) and SYTO 9 (Thermo Fisher Scientific, Scoresby, VIC, Australia) were used to stain the yeast cells for fluorescence microscopy [39]. S. cerevisiae cells were fixed in $4 \%$ paraformaldehyde for $1 \mathrm{~h}$, harvested by centrifugation at $2500 \times g \mathrm{rpm}$ for $5 \mathrm{~min}$ and washed twice with $0.1 \mathrm{M}$ phosphate buffered 
saline. DAPI (50 $\mathrm{ng} / \mathrm{mL})$ was mixed with the yeast cell suspension at a 1:1 $(v / v)$ ratio. SYTO $9(5 \mathrm{mM})$ was mixed with the cell suspension at a 1:1000 $(v / v)$ ratio. Cells were allowed to stain in the dark at $25^{\circ} \mathrm{C}$ for $15 \mathrm{~min}$, then $8 \mu \mathrm{L}$ were transferred to a microscope glass slide and covered with a coverslip. Cells were observed with a Leica DM6000B microscope using a $100 \times$ objective (Leica, Wetzlar, Germany). Images were captured with a Leica DFC420C digital camera and Microsystem LAS AF6000 software (Leica).

\subsection{Scanning Electron Microscopy}

Yeast cells were initially fixed in glutaraldehyde and then in 1\% osmium tetroxide. Cells were dehydrated through a series of ethanol washes, transferred to coverslips coated with $1 \mathrm{mg} / \mathrm{mL}$ poly-L-lysine, dried in a critical point dryer (Tousimis Research Corp., Rockville, MD, USA) and coated with gold according to the manufacturer's instructions using a sputter coater (Agar Scientific Ltd., Essex, UK). Images were captured with a JCM5000 NeoScopeTM Table Top scanning electron microscope (Jeol Neoscope/Australasia, Frenchs Forest, NSW, Australia) at an accelerating voltage of $10 \mathrm{kV}$.

\subsection{Gas Chromatography (GC)-Mass Spectrometry Analysis}

EOs were analyzed for bioactive compounds as described by Chaliha et al. [40] with slight modifications. A Trace GC Ultra system coupled with a DSQ mass spectrometer (MS) (Thermo Fisher Scientific) was used. The bioactive compounds were separated by a Factor Four capillary column VF- $5 \mathrm{~ms}(30 \mathrm{~m} \times 0.25 \mathrm{~mm} \times 0.25 \mu \mathrm{m}$; Varian Inc., Palo Alto, CA, USA) under the following conditions: sample injection volume of $1 \mu \mathrm{L}$; temperature program, $1.5 \mathrm{~min}$ at $30{ }^{\circ} \mathrm{C}$, increase to $200^{\circ} \mathrm{C}$ at $10^{\circ} \mathrm{C} / \mathrm{min}$ intervals, $1 \mathrm{~min}$ at $200^{\circ} \mathrm{C}$, then increase to $220^{\circ} \mathrm{C}$ within $1 \mathrm{~min}, 2 \mathrm{~min}$ at $220^{\circ} \mathrm{C}$ before returning to the initial setting; helium was used as a carrier gas with a flow rate of $1.5 \mathrm{~mL} / \mathrm{min}$. Mass spectra were recorded from 40-390 amu (atomic mass unit) with a scan time of $0.14 \mathrm{~s}$.

\subsection{Statistical Analysis}

Statistical analysis was performed using GraphPad Prism version 7.00 (GraphPad, San Diego, CA, USA) and figures were generated in Microsoft Excel (Microsoft Corp., Redmond, WA, USA). Differences between treatment groups were evaluated using one-way ANOVA followed by Tukey's HSD test and $p<0.05$ was considered significant.

\section{Results}

\subsection{Antimicrobial Properties}

The MICs, MFCs and MBCs of EOs and standard antibiotic drugs against yeasts and bacteria are presented in Table 1 . The EO of AM did not show antimicrobial activity against the tested microorganisms below $2 \%(20 \mathrm{mg} / \mathrm{mL})$. TPL and LM EOs demonstrated a broad-spectrum of weak-acid resistant anti-yeast and antibacterial activity. The range of anti-yeast and antibacterial MICs for TPL EO was $0.03-0.07 \mathrm{mg} / \mathrm{mL}$ and $0.22-0.42 \mathrm{mg} / \mathrm{mL}$, respectively, and $0.07-0.31 \mathrm{mg} / \mathrm{mL}$ and $0.83-1.67 \mathrm{mg} / \mathrm{mL}$ for LM EO. However, the MICs of chloramphenicol against S. aureus and E. coli were 20.82 and $26.03 \mu \mathrm{g} / \mathrm{mL}$, which is considerably lower than the MICs of LM $(0.83$ and $1.67 \mathrm{mg} / \mathrm{mL})$ and TPL $(0.22$ and $0.42 \mathrm{mg} / \mathrm{mL}$ ) EOs. Overall, TPL and LM EOs demonstrated anti-yeast and antibacterial activities, but were less potent than the standard antifungal agent, amphotericin B, and standard antibacterial agent, chloramphenicol. TPL EO had a stronger anti-yeast activity than LM EO, with MICs ranging from 0.03 to $0.07 \mathrm{mg} / \mathrm{mL}$ vs. 0.07 to $0.31 \mathrm{mg} / \mathrm{mL}$. Furthermore, the MICs of TPL EO were equal to the MFCs against $C$. albicans, S. cerevisiae, R. mucilaginosa, R. glutinis, S. pombe, D. anomala and D. bruxellensis, but lower than the MFCs against $Z$. rouxii, Z. bailii and C. krusei. In the experiments with LM EO, the MIC and MFC was equal only for C. albicans and lower for all other yeasts (MIC $<$ MFC). 
Table 1. Minimum inhibitory concentration, minimum fungicidal concentration and minimum bactericidal concentration of Tasmanian pepper leaf and lemon myrtle essential oils, amphotericin B and chloramphenicol against bacteria and yeasts.

\begin{tabular}{|c|c|c|c|c|c|c|c|c|}
\hline \multirow[b]{2}{*}{ Microorganisms } & \multicolumn{2}{|c|}{ TPL EO } & \multicolumn{2}{|c|}{ LM EO } & \multicolumn{2}{|c|}{ Amphotericin B } & \multicolumn{2}{|c|}{ Chloramphenicol } \\
\hline & $\underset{(\mathrm{mg} / \mathrm{mL})}{\mathrm{MIC}}$ & $\begin{array}{c}\mathrm{MBC} / \mathrm{MFC} \\
(\mathrm{mg} / \mathrm{mL})\end{array}$ & $\underset{(\mathrm{mg} / \mathrm{mL})}{\mathrm{MIC}}$ & $\begin{array}{c}\mathrm{MBC} / \mathrm{MFC} \\
(\mathrm{mg} / \mathrm{mL})\end{array}$ & $\underset{(\mu \mathrm{g} / \mathrm{mL})}{\mathrm{MIC}}$ & $\begin{array}{c}\text { MFC } \\
(\mu \mathrm{g} / \mathrm{mL})\end{array}$ & $\underset{(\mu \mathrm{g} / \mathrm{mL})}{\mathrm{MIC}}$ & $\begin{array}{c}\mathrm{MBC} \\
(\mu \mathrm{g} / \mathrm{mL})\end{array}$ \\
\hline E. coli & $0.42 \pm 0.02^{\mathrm{a}}$ & $0.42 \pm 0.02$ & $1.67 \pm 0.07^{\mathrm{a}}$ & $3.33 \pm 0.14$ & NT & NT & $26.03 \pm 1.81^{b}$ & $52.08 \pm 3.61$ \\
\hline S. aureus & $0.22 \pm 0.01^{\mathrm{a}}$ & $0.30 \pm 0.02$ & $0.83 \pm 0.04^{\mathrm{a}}$ & $0.83 \pm 0.04$ & NT & NT & $20.82 \pm 1.81^{b}$ & $41.67 \pm 3.61$ \\
\hline Z. rouxii & $0.05 \pm 0.002^{\mathrm{a}}$ & $0.08 \pm 0.01$ & $0.31 \pm 0.001^{\mathrm{a}}$ & $0.52 \pm 0.02$ & $5.20 \pm 0.45^{b}$ & $7.80 \pm 0.001$ & NT & NT \\
\hline Z. bailii & $0.07 \pm 0.002^{\mathrm{a}}$ & $0.09 \pm 0.01$ & $0.26 \pm 0.01^{\mathrm{a}}$ & $0.31 \pm 0.001$ & $13.02 \pm 0.90^{b}$ & $13.02 \pm 0.90$ & NT & NT \\
\hline C. albicans & $0.03 \pm 0.001^{\mathrm{a}}$ & $0.03 \pm 0.001$ & $0.26 \pm 0.01^{\mathrm{a}}$ & $0.26 \pm 0.01$ & $41.67 \pm 3.61^{\mathrm{b}}$ & $52.08 \pm 3.61$ & NT & NT \\
\hline S. cerevisiae & $0.05 \pm 0.003^{\mathrm{a}}$ & $0.05 \pm 0.002$ & $0.21 \pm 0.01^{\mathrm{a}}$ & $0.26 \pm 0.01$ & $3.25 \pm 0.23^{b}$ & $7.80 \pm 0.001$ & NT & NT \\
\hline R. mucilaginosa & $0.05 \pm 0.003^{\mathrm{a}}$ & $0.05 \pm 0.003$ & $0.21 \pm 0.01^{\mathrm{a}}$ & $0.42 \pm 0.02$ & $3.25 \pm 0.23^{b}$ & $6.50 \pm 0.45$ & NT & NT \\
\hline C. krusei & $0.03 \pm 0.001^{\mathrm{a}}$ & $0.04 \pm 0.001$ & $0.21 \pm 0.01^{\mathrm{a}}$ & $0.26 \pm 0.01$ & $3.25 \pm 0.23^{b}$ & $3.90 \pm 0.45$ & NT & NT \\
\hline R. glutinis & $0.03 \pm 0.001^{a}$ & $0.03 \pm 0.001$ & $0.21 \pm 0.01^{\mathrm{a}}$ & $0.37 \pm 0.02$ & $2.60 \pm 0.23^{b}$ & $5.21 \pm 0.45$ & NT & NT \\
\hline S. pombe & $0.07 \pm 0.008^{a}$ & $0.07 \pm 0.008$ & $0.16 \pm 0.001^{\mathrm{a}}$ & $0.21 \pm 0.01$ & $2.60 \pm 0.23^{b}$ & $6.50 \pm 0.45$ & NT & NT \\
\hline D. anomala & $0.03 \pm 0.001^{a}$ & $0.03 \pm 0.001$ & $0.11 \pm 0.01^{\mathrm{a}}$ & $0.13 \pm 0.005$ & $2.93 \pm 0.34^{b}$ & $3.90 \pm 0.001$ & NT & NT \\
\hline D. bruxellensis & $0.03 \pm 0.001^{\mathrm{a}}$ & $0.03 \pm 0.001$ & $0.07 \pm 0.002^{\mathrm{a}}$ & $0.11 \pm 0.004$ & $13.02 \pm 0.90^{\mathrm{b}}$ & $13.02 \pm 0.90$ & NT & NT \\
\hline
\end{tabular}

Data are means \pm SD $(n=3)$. Results for anise myrtle are not shown due to the lack of inhibitory activity below 20 mg/mL. NT: not tested. Minimum inhibitory concentration (MIC) values between treatments sharing different letters $(\mathrm{a}, \mathrm{b})$ are significantly $(p<0.05)$ different in each row. Minimum fungicidal concentration (MFC), minimum bactericidal concentration (MBC).

\subsection{Effect of Ergosterol on Yeast Cell Membranes}

The ergosterol binding assay was performed to examine if the EOs of LM and TPL are binding to the sterol (ergosterol) of the yeast plasma membrane. The affinity of EOs for ergosterol can be determined by comparing the MICs of EOs against yeasts in the absence or presence of exogenous ergosterol. If the EOs bind to ergosterol, they will readily form a complex and prevent the membrane from utilizing or interacting with them. The changes in the MICs of TPL and LM EOs against yeasts after adding ergosterol at different concentrations $(0,25,50$ and $100 \mu \mathrm{g} / \mathrm{mL})$ are presented in Figures 1 and 2. Increasing the exogenous ergosterol concentrations resulted in increased MICs for both EOs. The calculated correlation coefficient for LM EO $\left(R^{2}=0.771-0.996\right)$ and TPL EO $\left(R^{2}=0.771-0.986\right)$ showed a positive correlation between the added ergosterol concentrations and increased MICs, indicating a significant binding activity between the EOs and the added ergosterol (Table 2).

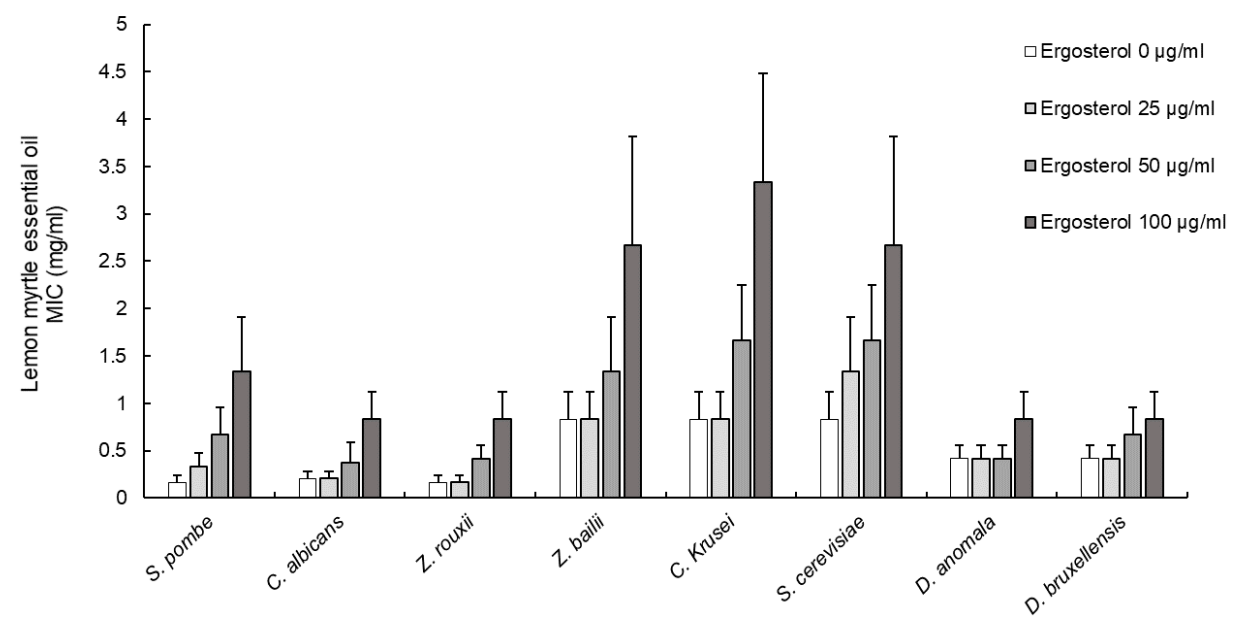

Figure 1. Changes in minimum inhibitory concentrations of lemon myrtle essential oil against yeasts in the absence and presence of exogenous ergosterol at different concentrations (comparative presentation). Data are means $\pm \mathrm{SD}(n=3)$. 


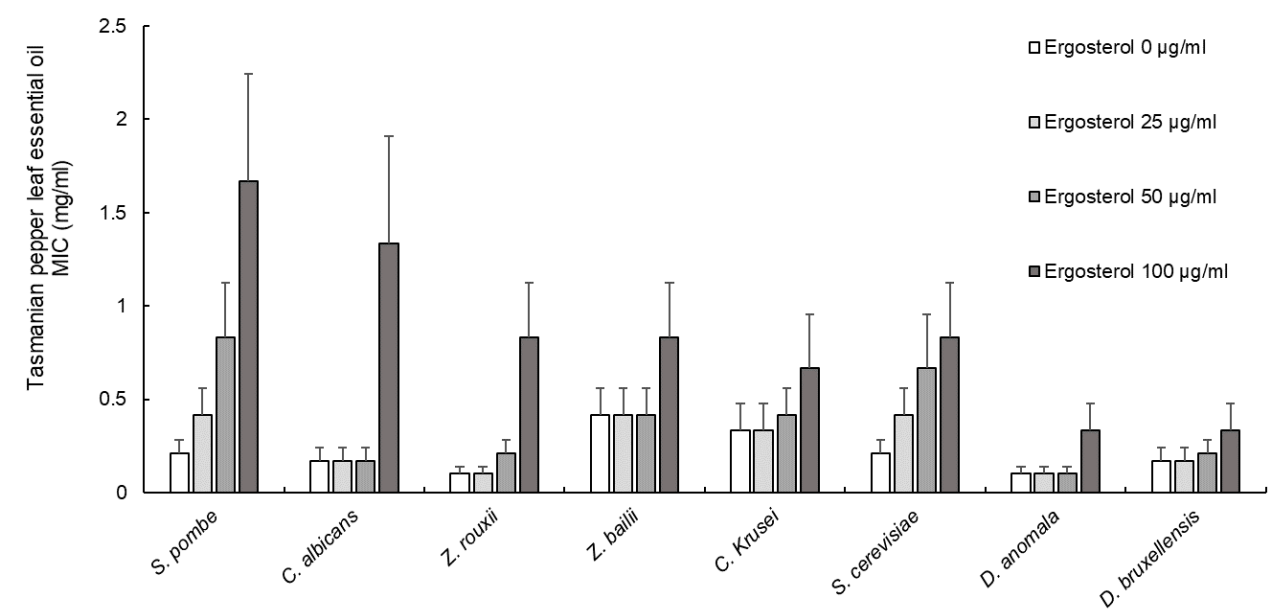

Figure 2. Changes in minimum inhibitory concentrations of Tasmanian pepper leaf essential oil against yeasts in the absence and presence of exogenous ergosterol at different concentrations (comparative presentation). Data are means $\pm \mathrm{SD}(n=3)$.

Table 2. Correlations between the added ergosterol $(0-100 \mu \mathrm{g} / \mathrm{mL})$ and corresponding minimum inhibitory concentrations of Tasmanian pepper leaf and lemon myrtle essential oils against yeasts.

\begin{tabular}{ccccccccc}
\hline & S. pombe & $\begin{array}{c}\text { C. } \\
\text { albicans }\end{array}$ & Z. rouxii & Z. bailii & C. Krusei & $\begin{array}{c}\text { S. } \\
\text { cerevisiae }\end{array}$ & $\begin{array}{c}\text { D. } \\
\text { anomala }\end{array}$ & $\begin{array}{c}\text { D. } \\
\text { bruxellensis }\end{array}$ \\
\hline $\begin{array}{c}\text { TPL EO and } \\
\text { ergosterol }\end{array}$ & $R^{2}$ & $0.986^{* *}$ & $0.771^{\mathrm{ns}}$ & $0.861^{\mathrm{ns}}$ & $0.771^{\mathrm{ns}}$ & $0.910^{*}$ & $0.938^{*}$ & $0.771^{\mathrm{ns}}$ \\
\hline $\begin{array}{c}\text { LM EO and } \\
\text { ergosterol }\end{array}$ & $R^{2}$ & $0.986^{* *}$ & $0.916^{*}$ & $0.940^{*}$ & $0.918^{*}$ & $0.933^{*}$ & $0.996^{* *}$ & $0.771^{\mathrm{ns}}$ \\
\hline
\end{tabular}

Values marked with an asterisk $\left(^{*}\right)$ indicate a correlation coefficient $\left(R^{2}\right)$ significant at $p$ value $<0.05$ and with double asterisk $\left(^{* *}\right)$ at $p$ value $<0.01$. Values marked with the letters (ns) indicate a non-significant correlation coefficient $\left(R^{2}\right)$ at $p$ value $>0.05$. Correlations determined based on changes in minimum inhibitory concentrations of Tasmanian pepper leaf (TPL) and lemon myrtle (LM) essential oils (EOs) when mixed with different exogenous ergosterol concentrations of $0,25,50$ and $100 \mu \mathrm{g} / \mathrm{mL}$.

\subsection{Effect of Sorbitol on Yeast Cell Wall}

The MICs of LM and TPL EOs against yeasts did not change after the addition of sorbitol to the growth medium, indicating that both EOs did not affect the yeast cell wall (data not shown).

\subsection{Quantification of Cellular Potassium and Magnesium Ions}

Penetration and disruption of the yeast cell membrane by EOs will destroy the cellular lipid bilayer structure and increase membrane fluidity and permeability, which leads to ion leakage. The leakage of potassium and magnesium ions from $S$. cerevisiae cells after 0 , 2, 4 and $6 \mathrm{~h}$ of exposure to TPL, LM and AM EOs are shown in Figure 3. The EOs of TPL and LM induced a significant $(p<0.05)$ leakage of potassium and magnesium ions from $S$. cerevisiae cells in a time-dependent manner. In contrast, AM EO caused only a slight non-significant $(p>0.05)$ leakage of potassium ions and did not affect the magnesium ions during the $6 \mathrm{~h}$ treatment period compared to the untreated control. Furthermore, the release of potassium ions from S. cerevisiae cells was considerably higher than that of magnesium ions. Overall, the observed significant leakage of potassium and magnesium ions from S. cerevisiae cells after the treatment with TPL and LM EOs indicate that both EOs interact with or damage the cytoplasmic membrane affecting its permeability for specific ions. 

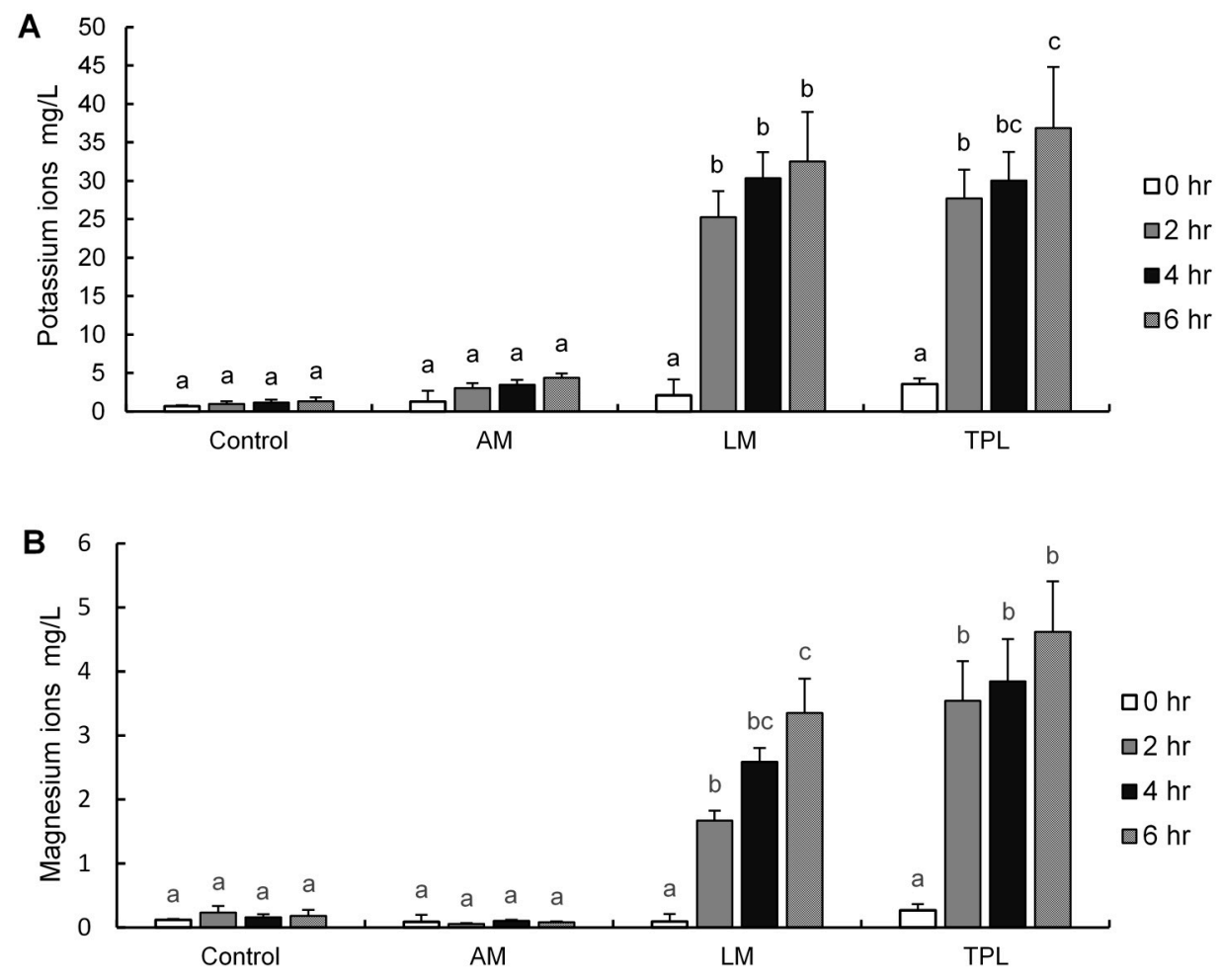

Figure 3. Leakage of potassium (A) and magnesium (B) ions from $S$. cerevisiae cells treated with anise myrtle, lemon myrtle and Tasmanian pepper leaf essential oils $(0.5 \%, v / v)$ for $0,2,4$ and $6 \mathrm{~h}$. Data are means $\pm \mathrm{SD}(n=3)$; means with different letters $(\mathrm{a}, \mathrm{b}, \mathrm{c})$ in the same column are significantly $(p<0.05)$ different.

\subsection{Synergic Effects of EOs}

The interactions between the EOs of TPL, LM and AM and their activity against nine yeasts produced different results, ranging from antagonistic to synergistic effects, depending on the EOs when combined at sub-inhibitory concentrations as well as the yeast (Table 3). The strongest synergistic effect was found between LM/TPL EOs effective against seven yeasts, followed by AM/TPL EOs effective against six yeasts and LM/AM EOs only effective against $R$. mucilaginosa. None of the EO combinations had an effect against $D$. anomala. 
Table 3. Effects of essential oils against yeasts and food related bacteria using the checkerboard method.

\begin{tabular}{|c|c|c|c|c|c|c|c|c|c|c|c|c|}
\hline \multirow{3}{*}{ Microorganisms } & \multicolumn{12}{|c|}{ Combinations } \\
\hline & \multicolumn{4}{|c|}{$\begin{array}{c}\text { TPL EO (A) } \\
+ \\
\text { LM EO (B) }\end{array}$} & \multicolumn{4}{|c|}{$\begin{array}{c}\text { TPL EO (A) } \\
+ \\
\text { AM EO (B) }\end{array}$} & \multicolumn{4}{|c|}{$\begin{array}{c}\text { LM EO (A) } \\
+ \\
\text { AM EO (B) }\end{array}$} \\
\hline & $\begin{array}{c}\text { MIC } \\
(v / v \%)\end{array}$ & $\begin{array}{c}\text { FIC } \\
(v / v \%)\end{array}$ & FICI & Action & $\begin{array}{c}\mathrm{MIC} \\
(v / v \%)\end{array}$ & $\begin{array}{c}\text { FIC } \\
(v / v \%)\end{array}$ & FICI & Action & $\begin{array}{c}\text { MIC } \\
(v / v \%)\end{array}$ & $\begin{array}{c}\text { FIC } \\
(v / v \%)\end{array}$ & FICI & Action \\
\hline S. pombe & $\begin{array}{l}0.016(\mathrm{~A}) \\
0.016(\mathrm{~B})\end{array}$ & $\begin{array}{l}0.004 \\
0.002\end{array}$ & 0.38 & Synergy & $\begin{array}{c}0.016(\mathrm{~A}) \\
>2.0(\mathrm{~B})\end{array}$ & $\begin{array}{l}0.008 \\
0.008\end{array}$ & 0.5 & Synergy & $\begin{array}{c}0.016(\mathrm{~A}) \\
>2.0(\mathrm{~B})\end{array}$ & $\begin{array}{l}0.016 \\
0.008\end{array}$ & 1 & Additive \\
\hline S. cerevisiae & $\begin{array}{l}0.031(\mathrm{~A}) \\
0.031(\mathrm{~B})\end{array}$ & $\begin{array}{l}0.008 \\
0.001\end{array}$ & 0.28 & Synergy & $\begin{array}{l}0.031(\mathrm{~A}) \\
>2.0(\mathrm{~B})\end{array}$ & $\begin{array}{l}0.016 \\
0.008\end{array}$ & 0.5 & Synergy & $\begin{array}{l}0.031(\mathrm{~A}) \\
>2.0(\mathrm{~B})\end{array}$ & $\begin{array}{l}0.031 \\
0.008\end{array}$ & 1 & Additive \\
\hline D. anomala & $\begin{array}{l}0.002(\mathrm{~A}) \\
0.008(\mathrm{~B})\end{array}$ & $\begin{array}{l}0.002 \\
0.008\end{array}$ & 1.95 & Indifferent & $\begin{array}{l}0.002(\mathrm{~A}) \\
>2.0(\mathrm{~B})\end{array}$ & $\begin{array}{c}0.004 \\
0.0625\end{array}$ & 1.95 & Indifferent & $\begin{array}{l}0.008(\mathrm{~A}) \\
>2.0(\mathrm{~B})\end{array}$ & $\begin{array}{l}0.016 \\
0.125\end{array}$ & 1.95 & Indifferent \\
\hline C. albicans & $\begin{array}{l}0.008(\mathrm{~A}) \\
0.063(\mathrm{~B})\end{array}$ & $\begin{array}{l}0.002 \\
0.016\end{array}$ & 0.49 & Synergy & $\begin{array}{l}0.008(\mathrm{~A}) \\
>2.0(\mathrm{~B})\end{array}$ & $\begin{array}{l}0.004 \\
0.063\end{array}$ & 0.49 & Synergy & $\begin{array}{l}0.063(\mathrm{~A}) \\
>2.0(\mathrm{~B})\end{array}$ & $\begin{array}{l}- \\
-\end{array}$ & & Antagonistic \\
\hline Z. bailii & $\begin{array}{l}0.031(\mathrm{~A}) \\
0.031(\mathrm{~B})\end{array}$ & $\begin{array}{l}0.008 \\
0.002\end{array}$ & 0.31 & Synergy & $\begin{array}{l}0.031(\mathrm{~A}) \\
>2.0(\mathrm{~B})\end{array}$ & $\begin{array}{l}0.008 \\
0.063\end{array}$ & 0.25 & Synergy & $\begin{array}{l}0.031(\mathrm{~A}) \\
>2.0(\mathrm{~B})\end{array}$ & $\begin{array}{c}0.031 \\
0.0625\end{array}$ & 0.99 & Additive \\
\hline Z. rouxii & $\begin{array}{l}0.004(\mathrm{~A}) \\
0.031(\mathrm{~B})\end{array}$ & $\begin{array}{c}0.002 \\
0.0005\end{array}$ & 0.5 & Synergy & $\begin{array}{l}0.004(\mathrm{~A}) \\
>2.0(\mathrm{~B})\end{array}$ & $\begin{array}{l}0.004 \\
0.008\end{array}$ & 0.98 & Additive & $\begin{array}{l}0.016(\mathrm{~A}) \\
>2.0(\mathrm{~B})\end{array}$ & $\begin{array}{l}0.031 \\
0.008\end{array}$ & 1 & Additive \\
\hline R. mucilaginosa & $\begin{array}{l}0.002(\mathrm{~A}) \\
0.016(\mathrm{~B})\end{array}$ & $\begin{array}{l}0.001 \\
0.004\end{array}$ & 0.74 & Additive & $\begin{array}{l}0.002(\mathrm{~A}) \\
>2.0(\mathrm{~B})\end{array}$ & $\begin{array}{c}0.0005 \\
0.031\end{array}$ & 0.24 & Synergy & $\begin{array}{l}0.016(\mathrm{~A}) \\
>2.0(\mathrm{~B})\end{array}$ & $\begin{array}{c}0.0005 \\
0.125\end{array}$ & 0.03 & Synergy \\
\hline R. glutinis & $\begin{array}{l}0.008(\mathrm{~A}) \\
0.016(\mathrm{~B})\end{array}$ & $\begin{array}{c}0.002 \\
0.0005\end{array}$ & 0.28 & Synergy & $\begin{array}{l}0.008(\mathrm{~A}) \\
>2.0(\mathrm{~B})\end{array}$ & $\begin{array}{l}0.004 \\
0.008\end{array}$ & 0.49 & Synergy & $\begin{array}{l}0.016(\mathrm{~A}) \\
>2.0(\mathrm{~B})\end{array}$ & $\begin{array}{l}0.016 \\
0.063\end{array}$ & 1 & Additive \\
\hline D. bruxellensis & $\begin{array}{l}0.002(\mathrm{~A}) \\
0.008(\mathrm{~B})\end{array}$ & $\begin{array}{l}0.0005 \\
0.0005\end{array}$ & 0.31 & Synergy & $\begin{array}{l}0.002(\mathrm{~A}) \\
>2.0(\mathrm{~B})\end{array}$ & $\begin{array}{l}0.002 \\
0.008\end{array}$ & 0.98 & Additive & $\begin{array}{l}0.008(\mathrm{~A}) \\
>2.0(\mathrm{~B})\end{array}$ & $\begin{array}{l}0.016 \\
0.063\end{array}$ & 1.95 & Indifferent \\
\hline
\end{tabular}

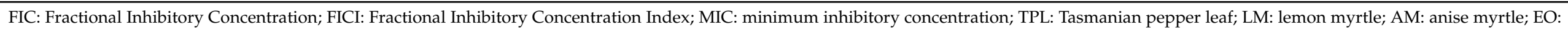
essential oil. 


\subsection{Microscopy of Yeast Cell Structure (Untreated and Treated)}

The untreated S. cerevisiae cells showed a normal oval-shaped cell structure with smooth and intact cell membranes without any signs of damage (Figure 4A,B and Figure 5A). Cells exposed to AM EO (Figure $5 \mathrm{~B}$ ) did not show any visible membrane damage, whereas cells exposed to LM EO (Figure 4C,D and Figure 5C) and TPL EO (Figure 4E,F and Figure 5D) had a deformed and disrupted cell structure that appeared swollen and expanded in size due to damage and lysis of the cell membrane. The organelles of untreated cells (Figure 4A,B) can be clearly seen within the cells' boundary, whereas organelles of damaged cells could not be seen within the cells due to their leakage through the disrupted membrane. The leaked organelles were visible outside the membrane-damaged cells in the bright-field microscopic images (Figure 4D,F). The scanning electron microscope produced detailed 3D images of pore formation on the membranes of cells exposed to LM (Figure 5C) and TPL (Figure 5D) EOs. Furthermore, the damaged cells had a wrinkled and uneven membrane with a larger round-shaped appearance compared to the untreated cells.

Fluorescence images
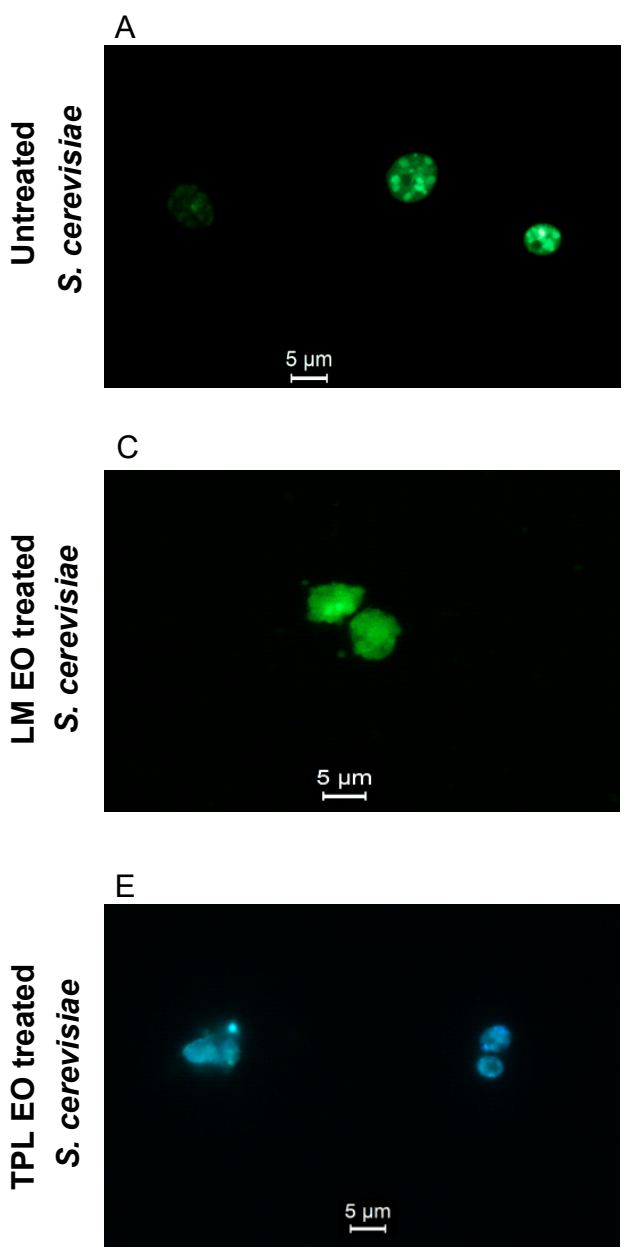

Bright-field images

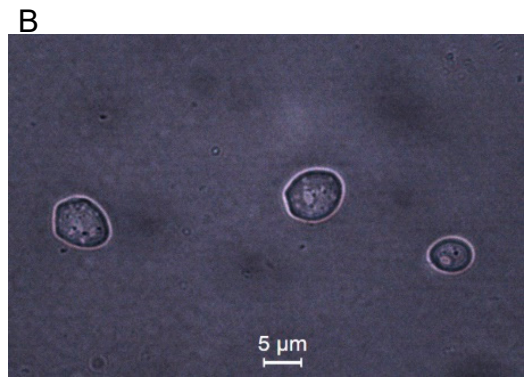

D

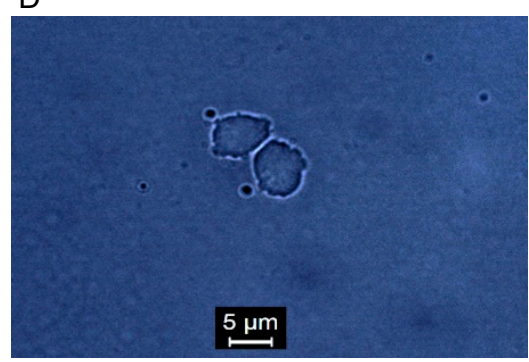

$\mathrm{F}$

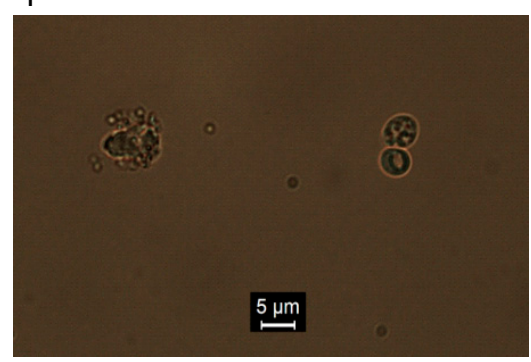

Figure 4. Fluorescence and bright-field electron microscopic images of untreated S. cerevisiae cells $(\mathbf{A}, \mathbf{B})$, and S. cerevisiae cells treated with essential oils from lemon myrtle $(\mathbf{C}, \mathbf{D})$ and Tasmanian pepper leaf $(\mathbf{E}, \mathbf{F})$. 
A

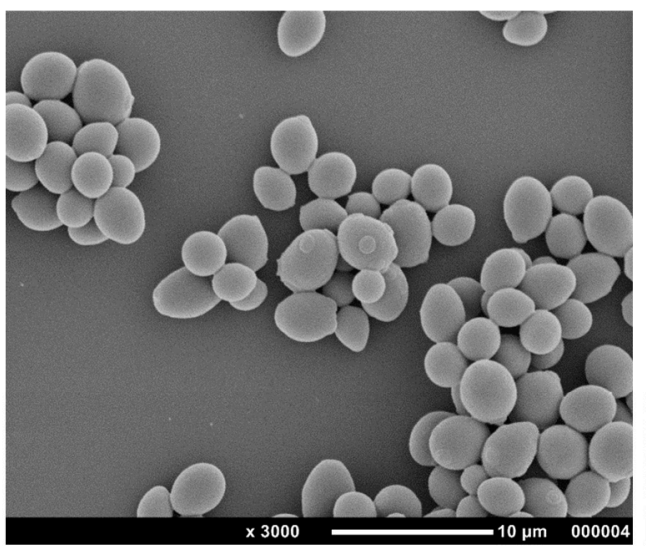

C

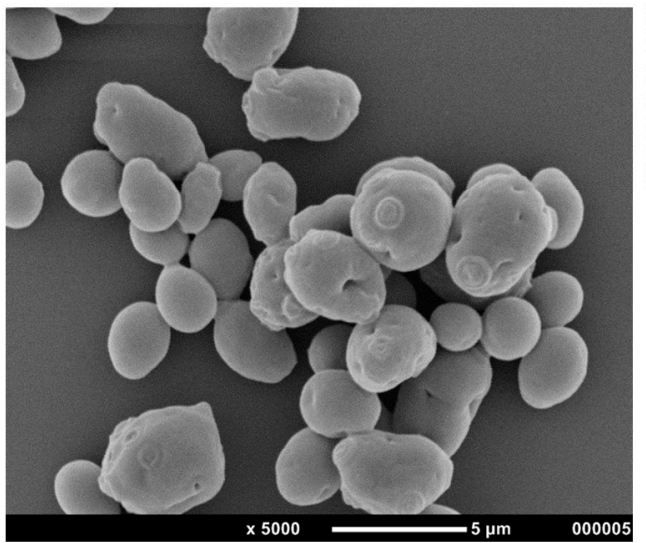

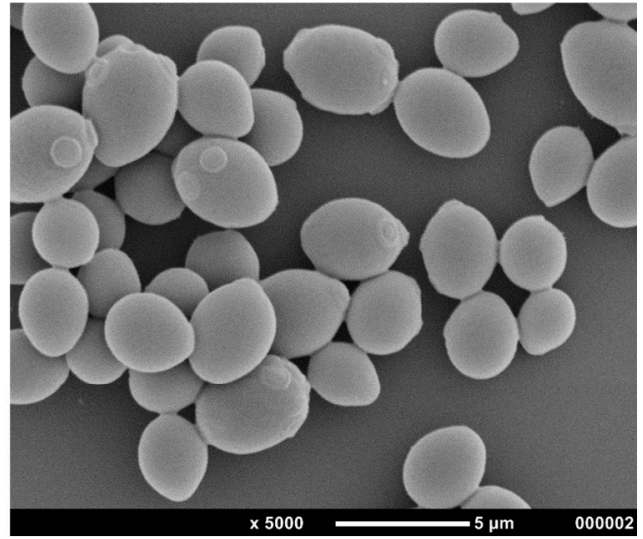

D

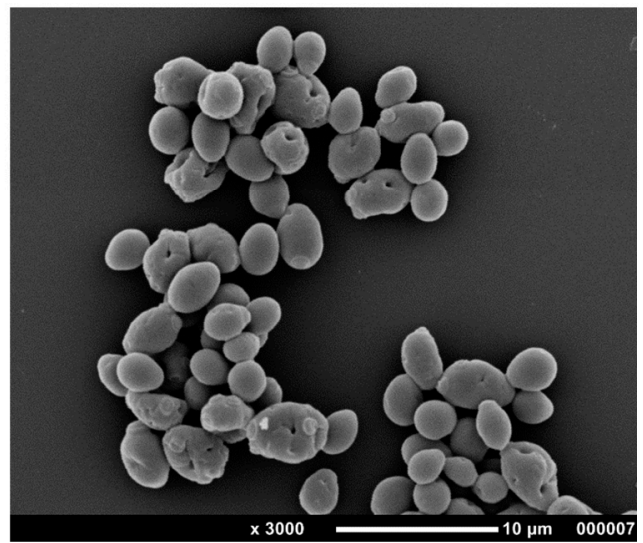

Figure 5. Scanning electron microscopic images of untreated S. cerevisiae cells (A), and S. cerevisiae cells treated with $0.5 \%(v / v)$ essential oils from anise myrtle (B), lemon myrtle $(\mathbf{C})$ and Tasmanian pepper leaf (D).

\subsection{Identification of the Main Bioactive Compounds in the Studied Eos}

The following compounds could be identified as the main 'bioactives' in the three Eos by GC-MS (qualitative analysis only): anethole $(11.70 \mathrm{~min})$ and methyl chavicol (10.11 $\mathrm{min}$ ) in AM EO (Figure 6A), polygodial (20.03) and guaiol (18.26 min) in TPL EO (Figure 6B), and neral (Z-isomer of citral; $10.84 \mathrm{~min}$ ) and geranial (E-isomer of citral; $11.30 \mathrm{~min}$ ) in LM EO (Figure 6C). Full chemical composition tests had been previously reported for commercially produced Eos of AM, TPL and LM and the results confirm our findings for the major identified bioactive compounds $[18,22,31,33]$. There are two chemotypes of AM that contain the same compounds but at different ratios, especially between anethole and its isomer methyl chavicol. The first chemotype of AM EO consists of anethole $(94.97 \%)$, methyl chavicol $(4.43 \%), \alpha$-pinene $(0.09 \%), 1,8$-Cineole $(0.02 \%)$ and $\alpha$-farnesene $(0.07 \%)$, and the second chemotype of AM EO has methyl chavicol (77.54\%), anethol $(19.95 \%), 1,8$-Cineole $(0.80 \%), \alpha$-pinene $(0.40 \%)$ and $\alpha$-farnesene $(0.11 \%)$ [31,33]. $\mathrm{C}\left(\mathrm{C}_{10} \mathrm{H}_{12} \mathrm{O}\right)$ and its isomer methyl chavicol (estragole) are phenylpropane aromatic compounds which were reported to possess antibacterial and antifungal properties [20,41-47]. Our findings showed that the two major compounds in AM EO are similar to the first chemotype where anethole being the major component followed by its isomer methyl chavicol. A full chemical profiling of TPL EO showed the following sesquiterpene $\left(\mathrm{C}_{15} \mathrm{H}_{24}\right)$ compounds: polygodial $(36.74 \%)$, guaiol $(4.46 \%)$, calamenene $(3.42 \%)$, spathulenol $(1.94 \%)$, drimenol (1.91\%), cadina-1,4-diene (1.58\%), 5-hydroxycalamenene $(1.47 \%)$ bicyclogermacrene $(1.15 \%), \alpha$-cubebene $(0.88 \%), \beta$-caryophyllene $(0.87 \%), \alpha$-copaene $(0.48 \%)$, cadalene $(0.44 \%)$, d-cadinol $(0.40 \%)$, elemol $(0.39 \%)$, T-muurolol $(0.39 \%)$, germacrene-D $(0.33 \%)$, and 
other sesquiterpenes compounds at levels below $0.16 \%$, camphene, $\alpha$-gurjunene, and $\beta$ cubebene [22]. Our results of GC-MS qualitative analysis were in agreement with Menary et al. [22] in which polygodial was the main compound in TPL EO followed by guaiol. Despite the fact that TPL EO contains some miner compounds in addition to its major constituent polygodial, most reports suggest that polygodial is the main contributor to the antibacterial and antifungal properties [18-20,23,48-54]. Plant Eos often contain several compounds where the antimicrobial activity arises from their major component; however, the minor compounds could form a complex synergistic interaction with the major compound, enhancing its antimicrobial action [55-57]. Previous chemical investigations reveal that LM EO predominantly $(82-91 \%)$ consists of citral $\left(\mathrm{C}_{10} \mathrm{H}_{16} \mathrm{O}\right)$ which is a monoterpene aldehyde that exists in two isomers geranial (E-isomer or citral $\mathrm{A}$ ) and neral (Z-isomer or citral B) $[30,58]$. According to three separate chemical profiling investigations of LM, EO showed the following constituents: geranial (45-49\%), neral (37-42\%), 5-Hepten-2one,6-methyl (1.54-13.82\%), 2,3-Dehydro-1,8-cineole (3.52\%), nerol (2.66\%), Germacrene B $(0.2-2.18 \%)$, geraniol $(0.8-1.26 \%)$, linalool $(0.5-5.85 \%)$, myrcene $(0.4-4.39 \%)$, and citronellal $(0.25-2.19 \%)[30,59,60]$. Our study showed the two major compounds in the tested LM EO are geranial and neral which is supported by the results reported by Forbes-Smith and Paton [30], Southwell et al. [59], and Pengelly [60]. The two major compounds geranial and neral (citral) contribute to the antimicrobial and antifungal activities in LM EO.

A

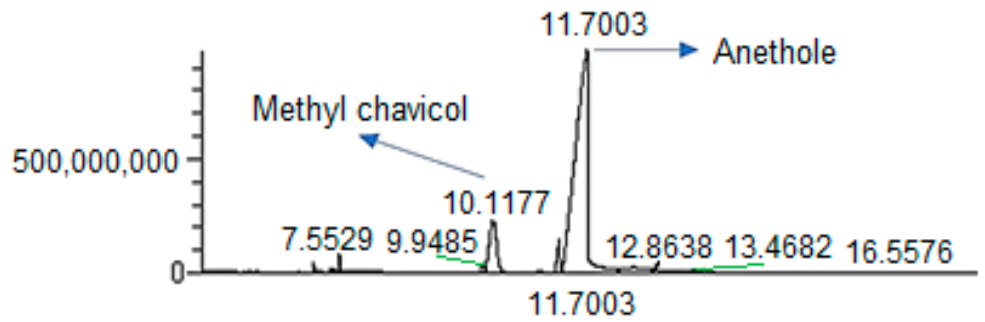

B

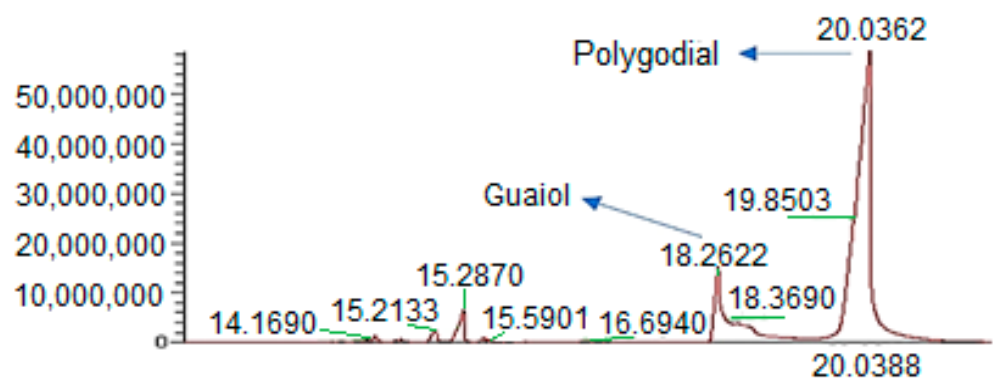

C

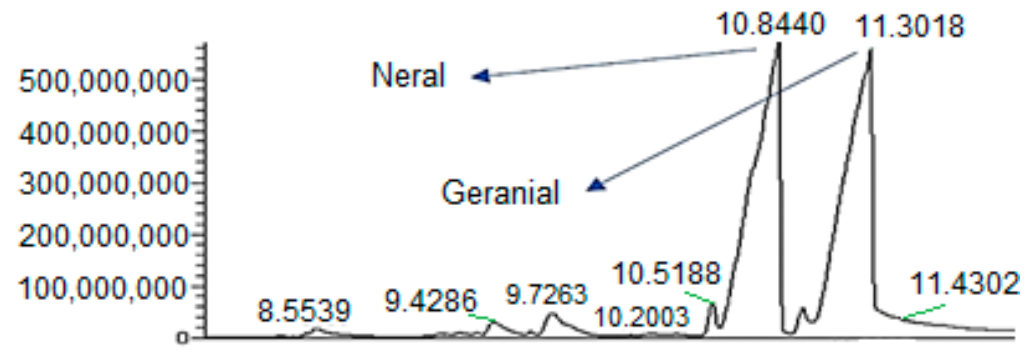

Figure 6. GC-MS chromatograms of anise myrtle (A), Tasmanian pepper leaf (B) and lemon myrtle (C) essential oils showing their main bioactive compounds.

\section{Discussion}

The EO of AM showed no antimicrobial activity against the tested microorganisms below $20 \mathrm{mg} / \mathrm{mL}$. Brophy and Boland [33] reported that the EO of AM can occur in two 
different chemotypes having the same chemical composition but at different concentrations: chemotype 1 contained anethole as the main bioactive compound with a relative concentration of 93 to $95 \%$ and methyl chavicol between 4.4 and $5.6 \%$, whereas chemotype 2 contained methyl chavicol as the main bioactive compound (66 to 77\%) and anethole as the minor one (20 to $33 \%$ ). The bioactive compound profile of AM EO in the present study is similar to chemotype 1 reported by Brophy and Boland, with anethole as the main bioactive compound followed by methyl chavicol at a much lower level. Wilkinson and Cavanagh [61] evaluated the antimicrobial activity of two AM EO samples: the first sample showed no activity against E. coli and C. albicans, while the second sample had an inhibitory effect against E. coli, S. aureus and C. albicans. In addition, a study by Hood et al. [62] reported antimicrobial activity of AM EO against E. coli and S. aureus, whereas Nirmal et al. [63] could not observe any activity against these bacteria. The controversial findings using AM EOs as an antimicrobial agent (effective vs. non-effective) are most likely caused by the reported significant variation in the content and ratio of anethole and methyl chavicol.

In contrast to the AM EOs, four different types of LM EOs studied by Wilkinson et al. [64] showed all a strong antibacterial and antifungal activity, which was positively correlated with citral, the main bioactive compound in these four EOs. Unlike the standard antibiotic drugs which possess either an antifungal or antibacterial effect, the tested EOs of LM and TPL had both antibacterial and anti(weak-acid resistant)-yeast activity. Polygodial, the main bioactive compound in TPL EO, was previously reported [65] to possess a stronger antifungal activity than the standard antifungal drug amphotericin B and also showed synergistic effects with antimicrobial drugs [53]. A study by Sultanbawa et al. [66] evaluated the inhibitory activity of LM EO and reported MICs of $0.313 \%$ against E. coli and $0.156 \%$ against $S$. aureus (complete inhibition after $22 \mathrm{~h}$ ). In the present study, LM EO completely inhibited the growth of E. coli and S. aureus after $24 \mathrm{~h}$ at MBCs of $0.167 \%(1.67 \mathrm{mg} / \mathrm{mL})$ for E. coli and $0.083 \%(0.83 \mathrm{mg} / \mathrm{mL})$ for $S$. aureus. Both studies revealed that Gram-positive bacteria were more susceptible to LM EOs than Gram-negative bacteria. Interestingly, the bacterial inhibition concentration of LM EO that prevented the growth of E. coli in the present study was almost the same as that reported by Sultanbawa et al. [66] (0.333 vs. $0.313 \%$ ). Overall, the results of both studies can be used to establish an effective concentration range for $\mathrm{LM} \mathrm{EO}$ against $E$. coli.

Furthermore, the MICs in the present study were similar to the MBCs/MFCs of TPL EO against D. bruxellensis, D. anomala, S. pombe, R. glutinis, S. cerevisiae, C. albicans and E. coli and for LM EO against $C$. albicans and S. aureus, which clearly indicates that both EOs exhibited a biocidal activity at their MIC levels. The pronounced biocidal activity of TPL EO against bacteria and yeasts, observed in the present study and many other studies, was attributed to polygodial, the main bioactive compound in TPL EO [20,21,48-54]. However, similar bactericidal and fungicidal properties have also been reported for LM EO and its main bioactive compound citral $[60,64,66-72]$. It should be mentioned that most available antifungal drugs possess only fungistatic activity and there is an increasing fungal resistance toward these drugs. Therefore, EOs from TPL and LM may offer an alternative strategy to tackle food spoilage offering both fungicidal and bactericidal activity $[20,21,49-54,63,68-71,73-76]$.

The fluorescence and scanning electron microscopic images of yeast cells treated with TPL and LM EOs revealed the fungicidal "mode of action" of these two EOs. Polygodial and citral have been reported to cause structural disruption of cell membranes, increase membrane permeability, and form channels or lesions in cytoplasmic membranes, causing leakage of intracellular components and finally cell death $[53,54,77]$. The observed yeast cell death in the present study was caused by multiple effects: cell membrane lysis, membrane pore formation and cell content leakage.

However, the addition of exogenous ergosterol had a diminishing effect on the antimicrobial activity of TPL and LM EOs against yeasts, resulting in increased MICs. Interactions between ergosterol and both EOs could be shown in the ergosterol binding assay. This 
interaction(s) can be described best as the binding of EOs (and their bioactive compounds) to ergosterol and thereby inhibiting or diminishing its crucial biological function in the cell membrane. Ergosterol is the main sterol component of fungal cell membranes and responsible for membrane rigidity, fluidity and permeability, contributing to the functionality of membrane bound enzymes and transporters [78]. Furthermore, the binding of (bioactive) compounds to ergosterol in yeast cell membranes is also affecting the integrity and fluidity of the membrane and can form microspores or channels where ions and cell content can leak through, eventually resulting in cell death. The mechanism of "killing" fungal cells by binding to ergosterol in the cell membrane has also been reported for other EOs and their bioactive compounds, such as thymol from Thymus vulgaris, carvacrol, geraniol, nerol and Coriandrum sativum leaf oil [35,79-81].

The sorbitol osmotic protection assay was performed to test potential effects of TPL and LM EOs on the integrity of the yeast cell wall. Increased MICs after the addition of sorbitol $(0.8 \mathrm{M})$ indicate an interaction between the EOs and the fungal cell wall. However, the MICs of TPL and LM EOs did not change after the addition of exogenous sorbitol to the test media which is a clear indication that the yeast cell wall was not affected by these two EOs. Our findings agree with literature reports about unchanged MICs of geraniol, thymol, nerol, eugenol, menthol and terpinen-4-ol after the addition of $0.8 \mathrm{M}$ sorbitol [80,82-84].

\section{Conclusions}

The present study could clearly demonstrate the antifungal activity of Australian native TPL and LM EOs against yeasts that are resistant to weak-acid preservatives and commonly cause serious spoilage problems for the beverage industry. Based on their "anti-yeast" effects, these EOs have the potential to be used as natural preservatives that could substitute, partly or totally, their synthetic counterparts in combating the increasing hazards of resistant yeasts to protect both the food industry and consumers.

Author Contributions: Conceptualization, F.A., R.M., S.W. and Y.S.; methodology, F.A.; software, F.A.; validation, R.M., S.W. and Y.S.; formal analysis, F.A.; investigation, F.A.; resources, R.M., S.W. and Y.S.; data curation, F.A.; writing-original draft preparation, F.A.; writing-review and editing, R.M., S.W., M.E.N. and Y.S.; visualization, F.A.; supervision, R.M., S.W. and Y.S.; project administration, Y.S.; funding acquisition, F.A. and Y.S. All authors have read and agreed to the published version of the manuscript.

Funding: This research was funded by the Public Authority for Applied Education and Training, Kuwait and the Queensland Alliance for Agriculture and Food Innovation, The University of Queensland, Brisbane, QLD, Australia.

Institutional Review Board Statement: Not applicable.

Informed Consent Statement: Not applicable.

Data Availability Statement: All relevant data are reported in the paper; the corresponding author, Yasmina Sultanbawa, should be contacted for furhter details.

Acknowledgments: The authors thank Brian Burren, Kinnari Shelat, Andrew Cusack and Margaret Currie for their expert technical assistance.

Conflicts of Interest: The authors declare no conflict of interest. The funders had no role in the design of the study; in the collection, analyses, or interpretation of data; in the writing of the manuscript, or in the decision to publish the results.

\section{References}

1. Burt, S. Essential oils: Their antibacterial properties and potential applications in foods-A review. Int. J. Food Microbiol. 2004, 94, 223-253. [CrossRef]

2. Rhind, J. From Historical Origins to the Present Day: The Philosophies of the Pioneers and Influential Thinkers. In Essential Oils: A Handbook for Aromatherapy Practice; Singing Dragon: London, UK; Philadelphia, PA, USA, 2012; Volume 2, pp. 12-23.

3. Bakkali, F.; Averbeck, S.; Averbeck, D.; Idaomar, M. Biological effects of essential oils-A review. Food Chem. Toxicol. 2008, 46, 446-475. [CrossRef] [PubMed] 
4. Shaaban, H.A.E.; Shibamoto, T.; El-Ghorab, A.H. Bioactivity of essential oils and their volatile aroma components: Review. J. Essent. Oil Res. 2012, 24, 203. [CrossRef]

5. Van de Braak, S.; Leijten, G. Essential Oils and Oleoresins: A Survey in The Netherlands and Other Major Markets in the European Union; CBI, Centre for the Promotion of Imports from Developing Countries: Rotterdam, The Netherlands, 1994.

6. Ndagijimana, M.; Belletti, N.; Lanciotti, R.; Guerzoni, M.; Ardini, F. Effect of Aroma Compounds on the Microbial Stabilization of Orange-based Soft Drinks. J. Food Sci. 2004, 69, SNQ20-SNQ24. [CrossRef]

7. Tiwari, B.K.; Valdramidis, V.P.; O’Donnell, C.P.; Muthukumarappan, K.; Bourke, P.; Cullen, P.J. Application of natural antimicrobials for food preservation. J. Agric. Food Chem. 2009, 57, 5987. [CrossRef]

8. Tajkarimi, M.M.; Ibrahim, S.A.; Cliver, D.O. Antimicrobial herb and spice compounds in food. Food Control 2010, 21, 1199-1218. [CrossRef]

9. Saad, N.Y.; Muller, C.D.; Lobstein, A. Major bioactivities and mechanism of action of essential oils and their components. Flavour Fragr. J. 2013, 28, 269-279. [CrossRef]

10. Gyawali, R.; Ibrahim, S.A. Natural products as antimicrobial agents. Food Control 2014, 46, 412-429. [CrossRef]

11. Stratford, M.; James, S.A. Non-alcoholic beverages and yeasts. In Yeasts in Food: Beneficial and Detrimental Aspects; Boekhout, T., Robert, V., Eds.; Woodhead Publishing Ltd.: Cambridge, UK, 2003; pp. 309-345.

12. Stratford, M.; Steels, H.; Nebe-von-Caron, G.; Novodvorska, M.; Hayer, K.; Archer, D.B. Extreme resistance to weak-acid preservatives in the spoilage yeast Zygosaccharomyces bailii. Int. J. Food Microbiol. 2013, 166, 126-134. [CrossRef] [PubMed]

13. Divol, B.; du Toit, M.; Duckitt, E. Surviving in the presence of sulphur dioxide: Strategies developed by wine yeasts. Appl. Microbiol. Biotechnol. 2012, 95, 601-613. [CrossRef]

14. Pitt, J.I.; Hocking, A.D. Spoilage of stored, processed and preserved foods. In Fungi and Food Spoilage, 3rd ed.; Springer: New York, NY, USA, 2009; pp. 401-419.

15. Hayashi, M.; Naknukool, S.; Hayakawa, S.; Ogawa, M.; Ni'matulah, A.-B.A. Enhancement of antimicrobial activity of a lactoperoxidase system by carrot extract and $\beta$-carotene. Food Chem. 2012, 130, 541-546. [CrossRef]

16. Newman, D.J.; Cragg, G.M. Natural products as sources of new drugs over the 30 years from 1981 to 2010. J. Nat. Prod. 2012, 75, 311-335. [CrossRef]

17. Krisch, J.; Rentsenkhand, T.; Vágvölgyi, C. Essential oils against yeast and moulds causing food spoilage. In Science against Microbial Pathogens: Communicating Current Research and Technological Advances Microbiology; Méndez-Vilas, A., Ed.; Formatex Research Center: Badajoz, Spain, 2011; pp. 1135-1142.

18. Pengelly, A. Indigenous and naturalised herbs: Tasmannia lanceolata: Mountain pepper. Aust. J. Med. Herbal. 2002, 14, 71-74.

19. Clarke, M. Australian Native Food Industry Stocktake; RIRDC Publication No. 12/066; Union Offset Printing: Canberra, Australia, 2012.

20. Fujita, K.-I.; Kubo, I. Naturally occurring antifungal agents against Zygosaccharomyces bailii and their synergism. J. Agric. Food Chem. 2005, 53, 5187-5191. [CrossRef]

21. Kubo, I.; Fujita, K.I.; Lee, S.H.; Ha, T.J. Antibacterial activity of polygodial. Phytother. Res. 2005, 19, 1013-1017. [CrossRef]

22. Menary, R.C.; Dragar, V.A.; Thomas, S.; Read, C.D. Mountain Pepper Extract, Tasmannia Lanceolata: Quality Stabilisation and Registration: A Report for the Rural Industries Research and Development Corporation; RIRDC: Barton, Australia, 2003.

23. Sultanbawa, Y. Tasmanian Pepper Leaf (Tasmannia lanceolata) Oils. In Essential Oils in Food Preservation, Flavor and Safety; Preedy, V.R., Ed.; Elsevier: Amsterdam, The Netherlands, 2016; pp. 819-823.

24. Cock, I.E. The phytochemistry and chemotherapeutic potential of Tasmannia lanceolata (Tasmanian pepper): A review. Pharmacogn. Commun. 2013, 3, 13-25.

25. Buchaillot, A.; Caffin, N.; Bhandari, B. Drying of lemon myrtle (Backhousia citriodora) leaves: Retention of volatiles and color. Dry. Technol. 2009, 27, 445-450. [CrossRef]

26. Jones, G.L. Asia and Australia-Essentially a Well Oiled Connection. In Aromatic Plants from Asia, their Chemistry and Application in Food and Therapy; Jirovetz, L., Dung, N.X., Varshney, V.K., Eds.; Har Krishnan Bhalla: Dehradun, India, 2007 ; p. 247.

27. Scheman, A.; Scheman, N.; Rakowski, E.-M. European directive fragrances in natural products. Dermatitis 2014, 25, 51-55. [CrossRef]

28. Ress, N.; Hailey, J.; Maronpot, R.; Bucher, J.; Travlos, G.; Haseman, J.; Orzech, D.; Johnson, J.; Hejtmancik, M. Toxicology and carcinogenesis studies of microencapsulated citral in rats and mice. Toxicol. Sci. 2003, 71, 198-206. [CrossRef]

29. Sultanbawa, Y. Lemon Myrtle (Backhousia citriodora) Oils. In Essential Oils in Food Preservation, Flavor and Safety; Preedy, V.R., Ed.; Elsevier: Amsterdam, The Netherlands, 2016; pp. 517-520.

30. Forbes-Smith, M.; Paton, J. Innovative products from Australian native foods. In Rural Industries Research and Development Corporation; RIRDC: Barton, Australia, 2002; pp. 1-78.

31. Blewitt, M.; Southwell, I.A. Backhousia anisata Vickery, an alternative source of (E)-anethole. J. Essent. Oil Res. 2000, 12, 445-454. [CrossRef]

32. Konczak, I.; Zabaras, D.; Dunstan, M.; Aguas, P. Antioxidant capacity and phenolic compounds in commercially grown native Australian herbs and spices. Food Chem. 2010, 122, 260-266. [CrossRef]

33. Brophy, J.J.; Boland, D.J. The leaf essential oil of two chemotypes of Backhousia anisata Vickery. Flavour Fragr. J. 1991, 6, 187-188. [CrossRef] 
34. Ahmad, A.; Viljoen, A. The in vitro antimicrobial activity of Cymbopogon essential oil (lemon grass) and its interaction with silver ions. Phytomedicine 2015, 22, 657-665. [CrossRef]

35. Lima, I.O.; Pereira, F.D.O.; Oliveira, W.A.D.; Lima, E.D.O.; Menezes, E.A.; Cunha, F.A.; Diniz, M.D.F.F.M. Antifungal activity and mode of action of carvacrol against Candida albicans strains. J. Essent. Oil Res. 2013, 25, 138-142. [CrossRef]

36. Frost, D.J.; Brandt, K.D.; Cugier, D.; Goldman, R. A whole-cell Candida albicans assay for the detection of inhibitors towards fungal cell wall synthesis and assembly. J. Antibiot. 1995, 48, 306-310. [CrossRef]

37. Prashar, A.; Hili, P.; Veness, R.G.; Evans, C.S. Antimicrobial action of palmarosa oil (Cymbopogon martinii) on Saccharomyces cerevisiae. Phytochemistry 2003, 63, 569-575. [CrossRef]

38. Zengin, H.; Baysal, A.H. Antibacterial and antioxidant activity of essential oil terpenes against pathogenic and spoilage-forming bacteria and cell structure-activity relationships evaluated by SEM microscopy. Molecules 2014, 19, 17773-17798. [CrossRef]

39. Shimada, S.; Andou, M.; Naito, N.; Yamada, N.; Osumi, M.; Hayashi, R. Effects of hydrostatic pressure on the ultrastructure and leakage of internal substances in the yeast Saccharomyces cerevisiae. Appl. Microbiol. Biotechnol. 1993, 40, 123-131. [CrossRef]

40. Chaliha, M.; Cusack, A.; Currie, M.; Sultanbawa, Y.; Smyth, H. Effect of packaging materials and storage on major volatile compounds in three Australian native herbs. J. Agric. Food. Chem. 2013, 61, 5738-5745. [CrossRef] [PubMed]

41. Karapinar, M.; Aktuğ, Ş.E. Inhibition of foodborne pathogens by thymol, eugenol, menthol and anethole. Int. J. Food Microbiol. 1987, 4, 161-166. [CrossRef]

42. Hançer Aydemir, D.; Cifci, G.; Aviyente, V.; Boşgelmez-Tinaz, G. Quorum-sensing inhibitor potential of trans-anethole aganist Pseudomonas aeruginosa. J. Appl. Microbiol. 2018, 125, 731-739. [CrossRef]

43. Dabrowska, M.; Zielińska-Bliźniewska, H.; Kwiatkowski, P.; Łopusiewicz, Ł.; Pruss, A.; Kostek, M.; Kochan, E.; Sienkiewicz, M. Inhibitory Effect of Eugenol and trans-Anethole Alone and in Combination with Antifungal Medicines on Candida albicans Clinical Isolates. Chem. Biodivers. 2021, 18, e2000843. [CrossRef]

44. Kubo, I.; Fujita, K.I.; Nihei, K.I. Antimicrobial activity of anethole and related compounds from aniseed. J. Sci. Food Agric. 2008, 88, 242-247. [CrossRef]

45. Huang, Y.; Zhao, J.; Zhou, L.; Wang, J.; Gong, Y.; Chen, X.; Guo, Z.; Wang, Q.; Jiang, W. Antifungal activity of the essential oil of Illicium verum fruit and its main component trans-anethole. Molecules 2010, 15, 7558-7569. [CrossRef] [PubMed]

46. Naksang, P.; Tongchitpakdee, S.; Thumanu, K.; Oruna-Concha, M.J.; Niranjan, K.; Rachtanapun, C. Assessment of antimicrobial activity, mode of action and volatile compounds of Etlingera pavieana essential oil. Molecules 2020, 25, 3245. [CrossRef]

47. Lis-Balchin, M.; Deans, S.G.; Eaglesham, E. Relationship between bioactivity and chemical composition of commercial essential oils. Flavour Fragr. J. 1998, 13, 98-104. [CrossRef]

48. Kubo, I.; Himejima, M. Anethole, a synergist of polygodial against filamentous microorganisms. J. Agric. Food Chem. 1991, 39, 2290-2292. [CrossRef]

49. Kubo, I.; Fujita, K.I.; Lee, S.H. Antifungal mechanism of polygodial. J. Agric. Food Chem. 2001, 49, 1607-1611. [CrossRef] [PubMed]

50. Machida, K.; Tanaka, T.; Taniguchi, M. Depletion of glutathione as a cause of the promotive effects of polygodial, a sesquiterpene on the production of reactive oxygen species in Saccharomyces cerevisiae. J. Biosci. Bioeng. 1999, 88, 526-530. [CrossRef]

51. Himejima, M.; Kubo, I. Fungicidal activity of polygodial in combination with anethole and indole against Candida albicans. $J$. Agric. Food Chem. 1993, 41, 1776-1779. [CrossRef]

52. Fujita, K.-I.; Kubo, I. Multifunctional action of antifungal polygodial against Saccharomyces cerevisiae: Involvement of pyrrole formation on cell surface in antifungal action. Bioorg. Med. Chem. 2005, 13, 6742-6747. [CrossRef] [PubMed]

53. Kubo, I.; Taniguchi, M. Polygodial, an antifungal potentiator. J. Nat. Prod. 1988, 51, 22-29. [CrossRef]

54. Yano, Y.; Taniguchi, M.; Tanaka, T.; Oi, S.; Kubo, I. Protective effects of $\mathrm{Ca}^{2+}$ on cell membrane damage by polygodial in Saccharomyces cerevisiae. Agric. Biol. Chem. 1991, 55, 603-604. [CrossRef]

55. Bassolé, I.H.N.; Lamien-Meda, A.; Bayala, B.; Tirogo, S.; Franz, C.; Novak, J.; Nebié, R.C.; Dicko, M.H. Composition and Antimicrobial Activities of Lippia multiflora Moldenke, Mentha x piperita L. and Ocimum basilicum L. Essential Oils and Their Major Monoterpene Alcohols Alone and in Combination. Molecules 2010, 15, 7825. [CrossRef]

56. Bassolé, I.H.N.; Juliani, H.R. Essential oils in combination and their antimicrobial properties. Molecules 2012, 17, $3989-4006$. [CrossRef]

57. Delaquis, P.J.; Stanich, K.; Girard, B.; Mazza, G. Antimicrobial activity of individual and mixed fractions of dill, cilantro, coriander and eucalyptus essential oils. Int. J. Food Microbiol. 2002, 74, 101-109. [CrossRef]

58. Kuwahara, Y.; Suzuki, H.; Matsumoto, K.; Wada, Y. Pheromone study on acarid mites. XI. Function of mite body as geometrical isomerization and reduction of citral (the alarm pheromone). Appl. Entomol. Zool. 1983, 18, 30-39. [CrossRef]

59. Southwell, I.A.; Russell, M.; Smith, R.L.; Archer, D.W. Backhousia citriodora F. Muell. (Myrtaceae), a superior source of citral. J. Essent. Oil Res. 2000, 12, 735-741. [CrossRef]

60. Pengelly, A. Antimicrobial activity of lemon myrtle and tea tree oils. Aust. J. Med. Herbal. 2003, 15, 9.

61. Wilkinson, J.M.; Cavanagh, H. Antibacterial activity of essential oils from Australian native plants. Phytother. Res. 2005, 19, 643-646. [CrossRef]

62. Hood, J.R.; Wilkinson, J.M.; Cavanagh, H.M. Evaluation of common antibacterial screening methods utilized in essential oil research. J. Essent. Oil Res. 2003, 15, 428-433. [CrossRef]

63. Nirmal, N.P.; Mereddy, R.; Li, L.; Sultanbawa, Y. Formulation, characterisation and antibacterial activity of lemon myrtle and anise myrtle essential oil in water nanoemulsion. Food Chem. 2018, 254, 1-7. [CrossRef] [PubMed] 
64. Wilkinson, J.M.; Hipwell, M.; Ryan, T.; Cavanagh, H.M. Bioactivity of Backhousia citriodora: Antibacterial and antifungal activity. J. Agric. Food Chem. 2003, 51, 76-81. [CrossRef]

65. Andres, M.-I.; Forsby, A.; Walum, E. Polygodial-induced noradrenaline release in human neuroblastoma SH-SY5Y cells. Toxicol. Vitr. 1997, 11, 509-511. [CrossRef]

66. Sultanbawa, Y.; Cusack, A.; Currie, M.; Davis, C. An innovative microplate assay to facilitate the detection of antimicrobial activity in plant extracts. J. Rapid Methods Autom. Microbiol. 2009, 17, 519-534. [CrossRef]

67. Aoudou, Y.; Léopold, T.N.; Michel, J.D.P.; Franccedil, E.; Moses, M.C. Antifungal properties of essential oils and some constituents to reduce foodborne pathogen. J. Yeast Fungal Res. 2010, 1, 001-008.

68. Wuryatmo, E.; Klieber, A.; Scott, E.S. Inhibition of citrus postharvest pathogens by vapor of citral and related compounds in culture. J. Agric. Food Chem. 2003, 51, 2637-2640. [CrossRef]

69. Wannissorn, B.; Jarikasem, S.; Soontorntanasart, T. Antifungal activity of lemon grass oil and lemon grass oil cream. Phytother. Res. 1996, 10, 551-554. [CrossRef]

70. Onawunmi, G.O. Evaluation of the antimicrobial activity of citral. Lett. Appl. Microbiol. 1989, 9, 105-108. [CrossRef]

71. Silva, C.d.B.d.; Guterres, S.S.; Weisheimer, V.; Schapoval, E.E. Antifungal activity of the lemongrass oil and citral against Candida spp. Braz. J. Infect. Dis. 2008, 12, 63-66. [CrossRef]

72. Marques, A.M.; Lima, C.H.; Alviano, D.S.; Esteves, R.L.; Kaplan, M.A.C. Traditional use, chemical composition and antimicrobial activity of Pectis brevipedunculata essential oil: A correlated lemongrass species in Brazil. Emir. J. Food Agric. 2013, 25, 798-808. [CrossRef]

73. McCallion, R.F.; Cole, A.; Walker, J.; Blunt, J.; Munro, M. Antibiotic substances from New Zealand plants. Planta Med. 1982, 44, 134-138. [CrossRef]

74. Lim, T.K. Tasmannia lanceolata. In Edible Medicinal and Non-Medicinal Plants: Fruits; Springer: Dordrecht, The Netherlands, 2013; Volume 6, pp. 493-499.

75. Kubo, I.; Fujita, K.I. Naturally occurring anti-Salmonella agents. J. Agric. Food Chem. 2001, 49, 5750-5754. [CrossRef]

76. Banihashemi, Z;; Abivardi, C. Evaluation of fungicidal and fungistatic activity of plant essential oils towards plant pathogenic and saprophytic fungi. Phytopathol. Mediterr. 2011, 50, 245-256.

77. Taniguchi, M.; Yano, Y.; Tada, E.; Ikenishi, K.; Oi, S.; Haraguchi, H.; Hashimoto, K.; Kubo, I. Mode of action of polygodial, an antifungal sesquiterpene dialdehyde. Agric. Biol. Chem. 1988, 52, 1409-1414.

78. Abe, F.; Hiraki, T. Mechanistic role of ergosterol in membrane rigidity and cycloheximide resistance in Saccharomyces cerevisiae. Biochim. Biophys. Acta (BBA) Biomembr. 2009, 1788, 743-752. [CrossRef]

79. de Lira Mota, K.S.; de Oliveira Pereira, F.; de Oliveira, W.A.; Lima, I.O.; de Oliveira Lima, E. Antifungal activity of Thymus vulgaris L. essential oil and its constituent phytochemicals against Rhizopus oryzae: Interaction with ergosterol. Molecules 2012, 17, 14418-14433. [CrossRef]

80. Miron, D.; Battisti, F.; Silva, F.K.; Lana, A.D.; Pippi, B.; Casanova, B.; Gnoatto, S.; Fuentefria, A.; Mayorga, P.; Schapoval, E.E. Antifungal activity and mechanism of action of monoterpenes against dermatophytes and yeasts. Rev. Bras. Farmacogn. 2014, 24, 660-667. [CrossRef]

81. de Almeida Freires, I.; Murata, R.M.; Furletti, V.F.; Sartoratto, A.; de Alencar, S.M.; Figueira, G.M.; de Oliveira Rodrigues, J.A.; Duarte, M.C.T.; Rosalen, P.L. Coriandrum sativum L.(coriander) essential oil: Antifungal activity and mode of action on Candida spp., and molecular targets affected in human whole-genome expression. PLoS ONE 2014, 9, e99086.

82. de Castro, R.D.; de Souza, T.M.P.A.; Bezerra, L.M.D.; Ferreira, G.L.S.; de Brito Costa, E.M.M.; Cavalcanti, A.L. Antifungal activity and mode of action of thymol and its synergism with nystatin against Candida species involved with infections in the oral cavity: An in vitro study. BMC Complement. Altern. Med. 2015, 15, 417. [CrossRef] [PubMed]

83. Rajkowska, K.; Nowak, A.; Kunicka-Styczyńska, A.; Siadura, A. Biological effects of various chemically characterized essential oils: Investigation of the mode of action against Candida albicans and HeLa cells. RSC Adv. 2016, 6, 97199-97207. [CrossRef]

84. Leite, M.C.; de Brito Bezerra, A.P.; de Sousa, J.P.; de Oliveira Lima, E. Investigating the antifungal activity and mechanism(s) of geraniol against Candida albicans strains. Med. Mycol. 2015, 53, 275-284. [CrossRef] [PubMed] 